\title{
The use of mice as animal model for testing acute toxicity (LD-50) of toxic shock syndrome toxin
}

\author{
[Utilização de camundongos como modelo animal para a verificação da toxicidade aguda da \\ toxina-1 da sindrome do choque tóxico]

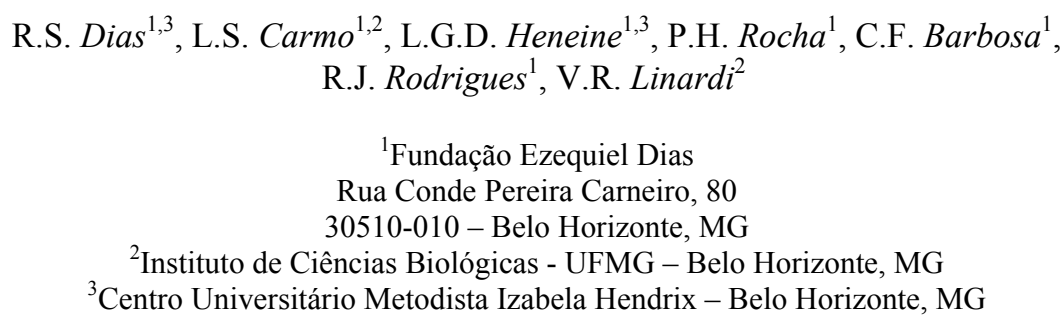

\begin{abstract}
Acute toxicity test (LD-50) using toxic shock syndrome toxin (TSST-1) was tested in BALB/c, C57BL/6 and Swiss mice. Animals $(\mathrm{n}=10)$ were intraperitoneally injected with TSST-1 $(0.01-10.0 \mu \mathrm{g} / \mathrm{mouse})$ followed $4 \mathrm{~h}$ later by potentiating dose of lipopolysaccharide (75.0 $\mu$ g of LPS - E. coli O111:B4) and cumulative mortality was recorded over 72h. Control animals received either TSST-1 or LPS alone. The data were submitted to quiSquare test and acute toxicity test was calculated by probit analysis (confidence limits expressed as $\mu \mathrm{g}$ toxin $/ \mathrm{kg}$ ). BALB $/ \mathrm{c}$ mice was the most sensitive $(20.0 \mu \mathrm{g} / \mathrm{kg}, 95 \%$ confidence limits: 9.0-92.0) followed by C57BL $/ 6(38.5 \mu \mathrm{g} / \mathrm{kg}, 95 \%$ confidence limits: 9.11- 401.6). Data from Swiss mice was not conclusive, indicating only low sensitivity. Selection of the animal model and standardization of the experiment are fundamental for the development of serum neutralization tests used for final quality control of vaccine production.
\end{abstract}

Keywords: mice, TSST-1, acute toxicity (LD-50), Staphylococcus

\section{RESUMO}

A toxicidade aguda (DL-50) da toxina da síndrome do choque tóxico (TSST-1) foi testada em linhagens de camundongos $B A L B / c$, C57BL/6 e Suiça. Os animais $(n=10)$ inoculados intraperitoneal com doses crescentes

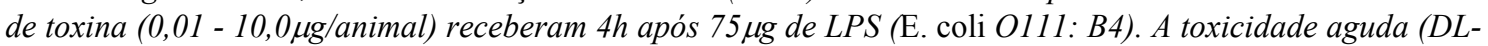
50) foi observada por um periodo de $72 \mathrm{~h}$ e os dados submetidos ao teste de qui-quadrado. Os resultados e os limites de confiança foram expressos em $\mu \mathrm{g}$ de toxina $/ \mathrm{kg}$. A linhagem BALB/c apresentou maior sensibilidade $(20 \mu \mathrm{g} / \mathrm{kg}$ - limite de confiança a 95\% entre 9,0-92,0), seguida da C57BL/6 (38,5 $\mathrm{gg} / \mathrm{kg}$ - limite de confiança a 95\% entre 9,11 - 401,6). A amplitude dos limites de confiança deve-se à natureza da toxina, ao mecanismo de ação, a via de inoculação e ao animal utilizado. A seleção do modelo animal e a padronização do experimento são fundamentais para o desenvolvimento de testes de soro neutralização para fins de controle de qualidade do processo de produção de vacinas.

Palavras-chave: camundongo, TSST-1, toxicidade aguda (DL-50), Staphylococcus

\section{INTRODUCTION}

Toxic shock syndrome (TSS) is an acute, severe, and multi-systemic disease associated with colonization and infection of different sites of the human and animal body by Staphylococci strains. These strains produce a superantigen exotoxin named toxic shock syndrome toxin-1 (TSST-1), that is responsible for the signs and characteristic symptoms of the disease

Recebido em 5 de novembro de 2007

Aceito em 26 de novembro de 2008

E-mail: ricardo.dias@funed.mg.gov.br

Apoio: FAPEMIG 
(Parsonnet and Kasper, 1992). TSST-1 is a single-chain polypeptide of $22 \mathrm{KDa}$ molecular mass lacking disulfide bonds. It is secreted as a mature protein of 194 amino acids in length and belongs to a group of related pyrogenic staphylococcal and streptococcal exotoxins known to behave as superantigens (BlomsterHautamaa et al., 1986). The microorganism has also been isolated from severe cases of animal mastitis (Jones and Wieneke, 1986; Matsunaga et al., 1993).

The effects of TSST-1 in human are not well established maybe because of the absence of an animal model in which these effects could be studied. Several authors used rabbits and monkeys as well as germ-free animals as experimental model, testing different inoculation methods. Bulanda et al. (1989) compared the effects of TSST-1 in conventional and germ-free animals. Rabbits and piglets developed similar reactions, but the authors observed that germfree animals are less sensitive to toxin action than conventional animals. These results suggest that the indigenous microbiota has an important influence on the development of the signs and symptoms induced by TSST-1.

Because of the difficulties in maintaining and in handling such animals, new experimental animal models are proposed herein to study TSST-1 effects. Uchiyama et al. (1989), using $\mathrm{C} 3 \mathrm{H} / \mathrm{HeN}$ and BALB/c mice, found that TSST-1 lethality was associated with the toxin linkage to the molecules of main histocompatibility complex class II (MHC II), which was variable depending on mouse strain. Henne et al. (1991) suggested the $\mathrm{C} 3 \mathrm{H} / \mathrm{HeN}$ mouse strain for testing TSST-1 effect on tumoral necrose factor (TNF) production.

The present study had the objective of selecting an animal model for testing the TSST-1 acute toxicity (LD-50) that could be applied to examine the protection efficacy of TSST-1 vaccines.

\section{MATERIAL AND METHODS}

The experiment was carried out at the Service of Biological Control, Department of Quality Control, Fundação Ezequiel Dias (FUNED), Belo Horizonte, Brazil. The method was based on the determination of the toxin dose capable of killing at least $50 \%$ of the animals. The dose was determined by regression analysis of a dose/response curve. TSST-1 was produced in the laboratory of staphylococcal enterotoxins of FUNED, according to Carmo (2001)

The mouse model tested was based on data from Uchiyama et al. (1989) and Stiles et al. (1995). The acute toxicity (LD-50) of TSST-1 was tested in isogenic pathogen-free BALB/c, C57BL/6 (CEBIO-UFMG), or Swiss (FUNED) mice. Females weighing from 16.0 to $22.0 \mathrm{~g}$ were used.

Animals were housed in a specific pathogen-free environment and were distributed in groups, kept in polypropylene cages and fed laboratory chow and water ad libitum during the whole experiment.

For determination of LD-50 of TSST-1, an exploratory assay with each tested mouse strain was performed in order to exactly determine the dose range to be used with accuracy in the LD50 determination. After the initial exploratory assay, the dose range was set between 0.005 to $10.0 \mu \mathrm{g}$ of toxin per animal (equivalent doses of 0.025 to $500.0 \mu \mathrm{g}$ of toxin/kilogram). The elected doses for the lethality test were those capable of inducing mortality from $20 \%$ to $80 \%$.

Test group animals ( $\mathrm{n}=10$ animals $)$ were intraperitoneally inoculated (IP) with doses ranging from 0.01 to $10.0 \mu \mathrm{g} /$ animal, diluted in PBS, followed four hours later by a nonlethal, potentiating dose of $75.0 \mu \mathrm{g}$ of Escherichia coli O111:B4 lipopolysaccharide (LPS) ${ }^{1}$ diluted in PBS. The control animals $(n=10)$ received either TSST-1 (one dose of 5.0 $\mu \mathrm{g} / \mathrm{animal}$ of the purified toxin) or LPS alone $(75.0 \mu \mathrm{g}$ of LPS/animal). Lethality was recorded over 72 hours after the inoculation (Stiles et al., 1995).

The TSST-1 LD-50 was calculated by probit analysis with $95 \%$ confidence limits from data pooled from at least three experiments. The data were submitted to analysis of variance in order to verify if they obeyed a linear regression by the $\chi^{2}$ test. The LD-50 value was expressed as micrograms of toxin per mouse and the confidence limits were determined using the Fieller theorem (Finney, 1971).

${ }^{1}$ Sigma - Aldrich Co. - Saint Louis, USA. 


\section{RESULTS AND DISCUSSION}

The determination of TSST-1 acute toxicity (LD50) potentiated with $E$. coli LPS using BALB/c mice as experimental model was previously described by Sugyama et al. (1964) and Stiles et al. (1995).

Results showed BALB/c mice with a tendency to a higher sensitivity to the lethal effects of TSST1 potentiated by LPS when compared to mice of the C57BL/6 strain. The LD-50 for LPSpotentiated TSST-1 was $20.0 \mu \mathrm{g} / \mathrm{kg}(0.40 \mu \mathrm{g}$ per mouse and $95 \%$ confidence limit from $9.0 \mu \mathrm{g} / \mathrm{kg}$ to $92.0 \mu \mathrm{g} / \mathrm{kg})$ and $38.5 \mu \mathrm{g} / \mathrm{kg}(0.7 \mu \mathrm{g}$ per mouse and $95 \%$ confidence limit from $9.11 \mu \mathrm{g} / \mathrm{kg}$ to $401.6 \mu \mathrm{g} / \mathrm{kg}$ ) for $\mathrm{BALB} / \mathrm{c}$ and $\mathrm{C} 57 \mathrm{BL} / 6$ mice, respectively. Results obtained with Swiss mice were not conclusive, but indicated a much lower sensitivity.

Sensitivity differences of mice strains to bacterial superantigens were probably related to the type of MHC class II found on antigen-presenting cells and V $\beta$ populations among $\mathrm{T}$ cells (Choi et al., 1990). The mean value of the TSST-1 LD-50 obtained for BALB/c mice was 2.38 times lower than that of Stiles et al. (1995) $(47.2 \mu \mathrm{g} / \mathrm{kg}$ $0.94 \mu \mathrm{g} /$ mouse, $95 \%$ confidence limit of 15.2 $200 \mu \mathrm{g} / \mathrm{kg}$ ), but the confidence limits of both studies greatly overlap. These differences could be related to the origin and degree of purification of the TSST-1 toxin and also variations within the strains of mice. In the present study, BALB/c mice were more sensitive to the effects of TSST1 plus LPS than C57BL/6 strain which is in agreement with the results of Stiles et al. (1995). Bavari et al. (1999) determined the LD-50 for TSST-1 using the same mouse strain $(\mathrm{BALB} / \mathrm{c})$ as experimental model. Despite using a similar procedure, the LD-50 value found was 1.4 fold higher than the value described by Stiles et al. (1995) $(65.0 \mu \mathrm{g} / \mathrm{kg} ; 1.3 \mu \mathrm{g} / \mathrm{mouse})$ and 3.3 fold higher than that found in the present study. However, these differences were not statistically significant when the confidence limit of each experiment was considered.

The LD-50 varies according to nature of the toxin, action mechanism, production and purification methodology, inoculation route, and experimental animal model (gender, age, and strain). Such variables would probably be responsible for the wide confidence limits found in the present research. Because of the toxin nature, higher doses are necessary to induce death of the inoculated animal, except when the toxin is injected together with LPS. This is another example of endotoxin augmenting the toxicity of staphylococcal enterotoxins and TSST-1 (Henne et al., 1991).

In the animals injected only with TSST-1 no effect was observed, while in the animals injected only with LPS, chills and lethargy were observed. There was no death in both animal groups. According to Reeves et al. (1986), TSST-1 lethality can be associated with the inoculation route. The authors showed that the intravenous route in rabbits was more lethal than the subcutaneous. They also reported that older animals were more sensitive to the toxin than younger animals and that no gender effect was observed on the toxic effect of TSST-1.

\section{REFERENCES}

BAVARI, S.; ULRICH, R.G.; LE CLAIRE, R.D. Cross-reactive antibodies prevent the lethal effects of Staphylococcus aureus superantigens. J. Infect. Dis., v.180, p.1365-1369, 1999.

BLOMSTER-HAUTAMAA, D.A.; KREISWIRTH, B.N.; NOVICK, R.P. et al. Resolution of highly purified toxic-shock syndrome toxin 1 into two distinct proteins by isoeletric focusing. Biochemistry, v.9, p.25-54, 1986.

BULANDA, M.; ZALESKA, M.; MANDEL, L. et al. Toxicity of staphylococcal toxic shock syndrome toxin 1 goes germ free and conventional piglets. Rev. Infect. Dis., v.11, suppl.1, p. s:248-253, 1989.

CARMO, L.S. Produção e purificação em grande escala das enterotoxinas estafilocócicas $S E A, S E B, S E C_{2}, S E D$ e TSST-1 para uso em ensaios imuno-enzimáticos. 2001. 254f. Tese (Doutorado) - Instituto de Ciências Biológicas, Universidade Federal de Minas Gerais, Belo Horizonte.

CHOI, Y.; LAFFERTY, J.A.; CLEMENTS, J.R. et al. Selective expansion of $\mathrm{T}$ cells expressing $\mathrm{V} \beta 2$ in toxic shock syndrome. J. Exp. Med., v.172, p.981-984, 1990. 
FINNEY, D.J. Probits analysis. 3.ed. Cambridge: University Press, 1971.

HENNE, E.; CAMPBELL, W.H.; CARLSON, E. Toxic shock syndrome toxin 1 enhances synthesis of endotoxin - induced tumor necrosis factor in mice. Infect. Immun., v.59, p.29292933, 1991.

JONES, T.O.; WIENEKE, A.A. Staphylococcal toxic shock syndrome. Vet. Rec., v.25, p.34-45, 1986.

MATSUNAGA, T.; KAMATA, S.; KIKIICHI, N. Characteristics of Staphylococcus aureus isolated from peracute, acute, and chronic bovine mastitis. J. Med. Sci., v.55 p.297-300, 1993.

PARSONNET, J.; KASPER, D.L. Toxic shock syndrome: clinical developments and new biology. In: WILSON, J.D.; BRAUNWALD, E.; ISSELBACHER, K.J. et al. (Eds). Harrison's principles of internal medicine. 12.ed. New York: Mc Graw-Hill, 1992.
REEVES, M.W.; ARKO, R.J.; CHANLDER, F.W. et al. Affinity purification of staphylococcal toxic shock syndrome toxin-1 and its pathologic effect in rabbits. Infect. Immun., v.51, p.431-439, 1986.

STILES, B.G.; KRAKAUER, T.; BONVENTRE, P.F. Biological activity of toxic shock syndrome toxin 1 and a site - directed mutant, H135A, in a lipopolysaccharide potentiated mouse lethality model. Infect. Immun., p.1229-1234, 1995.

SUGYAMA, H.; MCKISSIC, E.M.; BERGDOLL, M.S. et al. Enhancement of bacterial endotoxin lethality by staphylococcal enterotoxin. J. Infect. Dis., v.114, p.111-118, 1964.

UCHIYAMA, T.; TADAKUMA, T.; IMANISHI, $K$. et al. Activation of murine $T$ cells by toxic shock syndrome toxin-1. $J$. Immunol., v.143, p.3175-3182, 1989. 